\title{
Penataan Kawasan Pasca Bencana Tanah Longsor Di Puncak Pass, Kecamatan Cipanas, Kabupaten Cianjur Tanggal 28 Maret 2018
}

\section{Post Landslide Disaster Area Arrangement in Puncak Pass, Cipanas Sub-District, Cianjur District on 28 March 2018}

Heru Sri Naryanto $^{\mathrm{a}}$, Firman Prawiradisastra ${ }^{\mathrm{b}}$, Agus Kristijono ${ }^{\mathrm{c}}$, Deliyanti Ganesha ${ }^{\mathrm{d}}$

${ }^{a}$ Peneliti Utama Pusat Teknologi Reduksi Risiko Bencana (PTRRB), Badan Pengkajian dan Penerapan Teknologi (BPPT), Gedung Geostech, Kompleks Puspiptek Serpong, Kota Tangerang Selatan, Indonesia [+62 8131880 3300]

${ }^{b}$ Perekayasa Muda Pusat Teknologi Reduksi Risiko Bencana, BPPT [+62 8121860 4821]

${ }^{c}$ Perekayasa Utama Pusat Teknologi Reduksi Risiko Bencana, BPPT [+62 8131044 1144]

${ }^{d}$ Perekayasa Pertama Pusat Teknologi Reduksi Risiko Bencana, BPPT [+62 8128788 9597]

\section{Article Info:}

Received: 23 - 05 - 2018

Accepted: 24 - $07-2019$

Keywords:

Landslide, Puncak Pass, debris slide, safe area arrangement.

Corresponding Author: Heru Sri Naryanto

Pusat Teknologi Reduksi Risiko

Bencana (PTRRB), Badan

Pengkajian dan Penerapan

Teknologi (BPPT), Gedung

Geostech, Kompleks Puspiptek

Serpong, Kota Tangerang

Selatan, Indonesia

Tel. +62-813-1880-3300

Email:

heru.naryanto@bppt.go.id

\begin{abstract}
Landslides often occur in Indonesia, including in Puncak which is a tourist area. A landslide disaster occurred at Puncak Pass, Cipanas Subdistrict, Cianjur District, West Java on Wednesday, March 28, 2018 at around 08.00 PM. Typology of landslides that occur is a debris slide consisting of debris materials such as soil, rocks and large trees, and form a basin such as the shape of a horseshoe on the former landslide. Landslide occurred on the slope of the road and destroyed the hotel building, the park behind the hotel and pine forest. Many factors that influence the occurrence of landslide in Puncak Pass, from the analysis there are three main factors causing the landslide: the topography of the landslide is very steep, the occurrence of heavy rain for several consecutive days before the occurrence of landslides, and the slope which always disrupted the transport load of vehicles on it. Arrangement of landslide areas is very important to re-arrange the sustainable condition of the area against similar landslide disaster in the future. These arrangements are: handling of landslides during emergency response, determining the location of new road development, water and drainage management, cliff strengthening, land management, potentially affected settlements, and landslide disaster management.
\end{abstract}

How to cite (CSE Style $8^{\text {th }}$ Edition):

Naryanto HS, Prawiradisastra F, Kristijono A, Ganesha D. 2019. Penataan Kawasan Pasca Bencana Tanah Longsor di Puncak Pass, Kecamatan Cipanas, Kabupaten Cianjur Tanggal 28 Maret 2018. JPSL 9(4): $1053-1065$. http://dx.doi.org/10.29244/jps1.9.4.1053-1065.

\section{PENDAHULUAN}

Akhir-akhir ini bencana tanah longsor (gerakan tanah) semakin sering terjadi di Indonesia, khususnya akibat curah hujan tinggi pada saat musim hujan. Kondisi tektonik di Indonesia yang membentuk morfologi tinggi, patahan, batuan vulkanik yang mudah rapuh serta ditunjang dengan iklim di Indonesia yang berupa tropis basah, sehingga menyebabkan potensi tanah longsor menjadi tinggi. Hal ini ditunjang dengan adanya degradasi perubahan tataguna lahan akhir-akhir ini, menyebabkan bencana tanah longsor menjadi semakin meningkat. Kombinasi faktor anthropogenik dan alam sering merupakan penyebab terjadinya longsor yang memakan korban jiwa dan kerugian harta benda. Upaya mitigasi diperlukan untuk meminimalkan dampak yang terjadi akibat bencana longsor (Naryanto, 2013; Naryanto et al., 2017). 
Tanah longsor merupakan proses perpindahan massa batuan (tanah) akibat gaya berat (gravitasi). Longsor terjadi karena adanya gangguan kesetimbangan gaya yang bekerja pada lereng yakni gaya penahan dan gaya peluncur. Gaya peluncur dipengaruhi oleh kandungan air, berat masa tanah itu sendiri berat beban bangunan. Ketidakseimbangan gaya tersebut diakibatkan adanya gaya dari luar lereng yang menyebabkan besarnya gaya peluncur pada suatu lereng menjadi lebih besar daripada gaya penahannya, sehingga menyebabkan masa tanah bergerak turun. Tanah longsor terjadi karena dua faktor utama yaitu faktor pengontrol dan faktor pemicu. Faktor pengontrol adalah faktor-faktor yang memengaruhi kondisi material itu sendiri seperti kondisi geologi, kemiringan lereng, litologi, sesar dan kekar pada batuan. Faktor pemicu adalah faktor yang menyebabkan bergeraknya material tersebut seperti curah hujan, gempabumi, erosi kaki lereng dan aktivitas manusia (Naryanto, 2011; Naryanto, 2013; Naryanto, 2016). Wang et al. (2017) mengatakan bahwa kejadian tanah longsor berhubungan dengan berbagai faktor seperti presipitasi, geologi, jarak dari patahan, vegetasi, dan topografi.

Beberapa peneliti telah mengklasifikasikan tanah longsor menjadi beberapa jenis. Varnes (1978) telah mengklasifikasikan tanah longsor menjadi 29 jenis yang dibagi dalam lima komponen utama, yaitu (i) yang berkaitan dengan pergerakan, (ii) yang berhubungan dengan material, (iii) yang berkaitan dengan geologi, geomorfologi, geografi, atau pengaturan iklim, (iv) berkaitan dengan ukuran atau geometri dan (v) yang berkaitan dengan usia atau keadaan aktivitasnya. Menurut PVMBG (2016), jenis tanah longsor berdasarkan kecepatan gerakannya dapat dibagi menjadi 5 (lima) jenis, yaitu: aliran, longsoran, runtuhan, amblesan, dan majemuk. Paimin et al. (2009) menjelaskan bahwa terdapat 2 variabel atau faktor penentu kerentanan longsor, yaitu: faktor alami dan factor manajemen. Faktor alami diantaranya: (i) curah hujan harian kumulatif 3 hari berturutan, (ii) kemiringan lahan, (iii) geologi atau batuan, (iv) keberadaan sesar/patahan, (v) kedalaman tanah sampai lapisan kedap; sedangkan dari faktor manajemen yaitu: (i) penggunaan lahan, (ii) infrastruktur, (iii) kepadatan permukiman.

Jumlah kejadian bencana tanah longsor tertinggi di Indonesia terjadi pada wilayah yang memiliki topografi yang curam dan memiliki curah hujan $2.000 \mathrm{~mm} /$ tahun. Bencana ini berkaitan erat dengan kondisi alam seperti jenis tanah, jenis batuan, curah hujan, kemiringan lahan dan penutup lahan. Selian itu faktor manusia sangat mempengaruhi terjadinya bencana tanah longsor, seperti alih fungsi lahan hutan yang tidak mengikuti aturan dan semena-mena, penebangan hutan tanpa melakukan tebang pilih, perluasan pemukiman di daerah dengan topografi yang curam (Sartohadi, 2008).

Bencana tanah longsor telah terjadi di Puncak Pass, Kecamatan Cipanas, Kabupaten Cianjur, Jawa Barat pada hari Rabu 28 Maret 2018 jam 20.00 WIB. Lokasi tersebut sebelumnya pernah terjadi longsor pada tanggal 5 Februari 2018, renovasi dengan pemasangan bronjong yang merupakan penanganan darurat pasca longsor yang sebelumnya pada lokasi tersebut hancur lagi akibat kejadian longsor terakhir. Bencana tanah longsor mempunyai panjang persebarannya sampai sejauh 125 meter. Longsor tersebut menimpa bangunan Puncak Pass Resort yang berada di bawahnya, berupa sebuah bungalow 3 lantai yang isinya 4 kamar mengalami rusak berat dan kantor hotel nyaris rata dengan tanah serta taman yang berada di belakang hotel mengalami rusak berat. Material longsoran terdiri dari bahan rombakan berupa tanah, batu serta pohon besar. Kejadian tanah longsor tersebut menyebabkan gangguan terhadap kondisi lalu-lintas di sepanjang jalan Puncak Pass yang merupakan daerah wisata. Pengaturan lalu lintas di Puncak Pass diberlakukan situasional, tergantung kemacetan yang terjadi (Naryanto et al., 2018).

Berdasarkan peta potensi pergerakan tanah yang dikeluarkan Badan Geologi menunjukkan bahwa kawasan Puncak termasuk daerah Puncak Pass berada dalam zona kerentanan gerakan tanah merah, artinya termasuk bencana longsor tinggi dan masih berpotensi untuk terjadi lagi di daerah tersebut (PVMBG, 2018). Identifikasi daerah kejadian longsor juga penting untuk mengetahui hubungan antara lokasi kejadian longsor dengan faktor persebaran geologi (batuan) dan tata guna lahan di daerah terjadinya longsor, sehingga dapat diketahui tata guna lahan yang sesuai pada setiap karakteristik lahan dan geologinya (Effendi \& Danil, 2008).

Maksud dari penelitian ini adalah untuk mengetahui fenomena terjadinya tanah longsor, dampak yang terjadi, faktor-faktor yang berpengaruh dan analisis mekanisme kejadiannya. Dengan diketahuinya 
permasalahan bencana tanah longsor tersebut, maka dapat dilakukan penataan kawasan di lingkungan tersebut yang efektif dan efisien yang aman terhadap bencana tanah longsor serupa.

\section{METODE}

\section{Lokasi dan Waktu Penelitian}

Lokasi penelitian dilakukan pada lokasi di sekitar tanah longsor telah terjadi di Puncak Pass, Kecamatan Cipanas, Kabupaten Cianjur, Jawa Barat, pada bulan Maret-Mei 2018.

\section{Metode Pengumpulan Data}

Metode pengumpulan data yang dilakukan adalah sebagai berikut:

- Persiapan dan koordinasi dengan instansi terkait.

- Kajian referensi/data sekunder berkaitan dengan kajian penelitian terdahulu tentang longsor yang terjadi di sekitar daerah Puncak, termasuk tentang daerah/lokasi, catatan-catatan instansi terkait, informasi dari penduduk, geologi, geomorfologi, struktur geologi, geologi tata lingkungan, geologi teknik, foto udara, curah hujan, DAS, hidrologi, drainase, sosial ekonomi, tata ruang atau RT/RW, penggunaan lahan, penduduk, geologi tata lingkungan, geologi teknik, foto udara dan lain-lain.

- Survei lapangan pasca bencana tanah longsor secara komprehensif. Survei pasca longsor meliputi pengamatan dampak kejadian, luasan, kemiringan lereng, topografi, jenis litologi, pengukuran kekuatan tanah, tataguna lahan, kondisi hidrologi, curah hujan, mataair, DAS, tataguna lahan, jenis vegetasi, sosial ekonomi masyarakat, diskusi dengan masyarakat setempat. Selai itu juga dilakukan pemetaan longsor dengan drone, pengukuran posisi dengan GPS Handheld dan kompas dengan teknik intersection.

- Pengolahan data referensi dan lapangan

- Analisis dan verifikasi data

- Penataan kawasan pasca terjadinya longsor

\section{Metode Analisis Data}

\section{Analisis Data Drone}

Salah satu metoda pengumpulan data adalah dengan pembuatan foto udara menggunakan drone, untuk mendapatkan data berupa still image lokasi survei. Dalam kegiatan tersebut digunakan drone tipe DJI Inspire. Pengambilan data dengan menggunakan berbagai kamera digital: compact, mirrorless, SLR, video, built-in. Pengumpulan data juga dilakukan dengan melihat data peta yang dapat diakses dan digunatakan seperti google map, apple map, maverick dan data peta lainnya. Pemrosesan data otomatis sepenuhnya dengan perangkat lunak desktop khusus (bentley context capture, pix4dmapper, agisoft photoscan) atau layanan cloud computing. Alur metode pembuatan foto udara dengan drone adalah: penetapan lokasi target, pembuatan rencana terbang, pengambilan data dengan drone, pengolahan data dengan drone, pembuatan kontur dan pembuatan peta (Gambar 1).

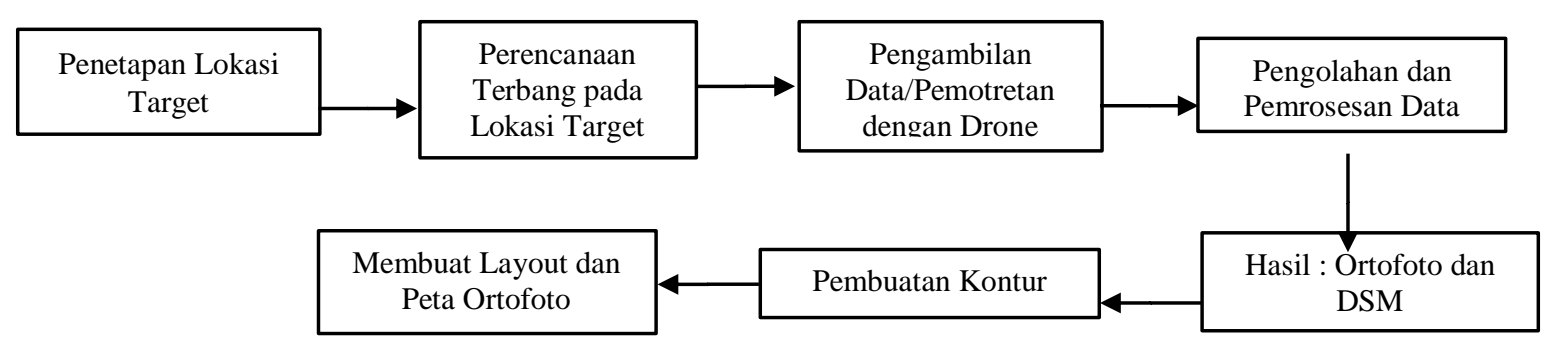

\section{Analisis Spasial}

Gambar 1 Alur metode pembuatan foto udara dengan drone. 
Analisis spasial dilakukan pada lokasi penelitian dengan tahapan proses sebagai berikut:

- Analisis peta kemiringan lereng dengan melakukan pengolahan data kontur rupabumi BIG Skala 1: 25.000 melalui extension spatial analyst pada software ArcGIS 10.6.

- Analisis peta sub DAS dengan melakukan pengolahan data kontur rupabumi BIG Skala 1:25.000 melalui software Global Mapper.

- Analisis overlay data spasial infrastruktur jalan, sungai, sub DAS dan citra World Imagery dengan menggunakan software Global Mapper untuk mengetahui kondisi tata ruang sebelum terjadi longsor.

- Analisis peta penggunaan lahan dengan menggunakan citra hasil drone melalui software ArcGIS 10.6 untuk delinisasi wilayah terdampak longsor pada lokasi penelitian, sehingga dapat diidentifikasi sebaran permukiman, kerusakan akibat longsor dan untuk dasar perencanaan tata ruang selanjutnya.

\section{Analisis Mekanisme Longsor}

Analisis mekanisme kejadian longsor sangat penting untuk pembelajaran dalam mengantisipasi kejadian serupa pada lokasi sekitar atau tempat lain. Berbagai parameter dalam analisis mekanisme kejadian longsor tersebut adalah: kondisi geologi, topografi, tataguna lahan, curah hujan, keairan dan drainase dan pengaruh aktivitas manusia.

\section{HASIL DAN PEMBAHASAN}

\section{Kondisi Kejadian Bencana Longsor}

Kejadian bencana tanah longsor di Puncak Pass, Kecamatan Cipanas, Kabupaten Cianjur, Jawa Barat pada hari Rabu 28 Maret 2018, mempunyai dimensi panjang mahkota longsor sekitar 50 meter dan menyempit ke arah bawah, panjang mahkota longsor sampai titik akhir material longsor sebesar 125 meter, arah gerakan tanah longsor relatif ke arah selatan - tenggara dan tinggi longsor pada mahkota longsor sekitar 25 meter. Dari penampang melintang terlihat profil topografi dan kelerengan dari daerah longsor. Kelerangan daerah longsor sekitar $70^{\circ}-80^{\circ}$ sementara kelerengan daerah landai tersebut adalah sekitar $20^{\circ}-30^{\circ}$. Tipologi tanah longsor yang terjadi di sekitar kawasan Puncak Pass Resort adalah longsoran bahan rombakan (debris slide) jenis rotasi, yaitu gerakan massa tanah yang membentuk cekungan seperti tapal kuda dengan mahkota longsor berada di tebing jalan raya (Gambar 2). Tipe longsor berupa rayapan disinyalir juga terjadi di bagian Puncak Pass Resort yang berdekatan dengan permukiman. Permukiman padat penduduk berada tidak terlalu jauh di bawah lokasi longsor (Gambar 3 dan 4).
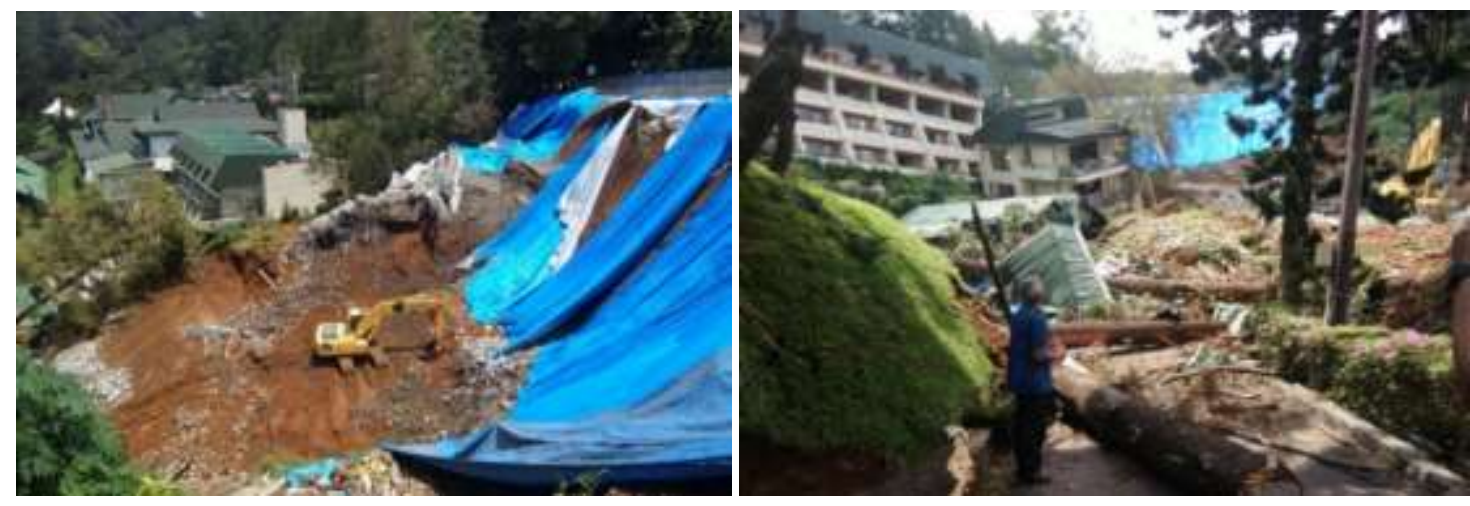

Gambar 2 Dampak bencana tanah longsor yang terjadi dan merusak bangunan resort berupa sebuah bungalow yang mengalami rusak berat serta kantor resort yang nyaris rata dengan tanah. 


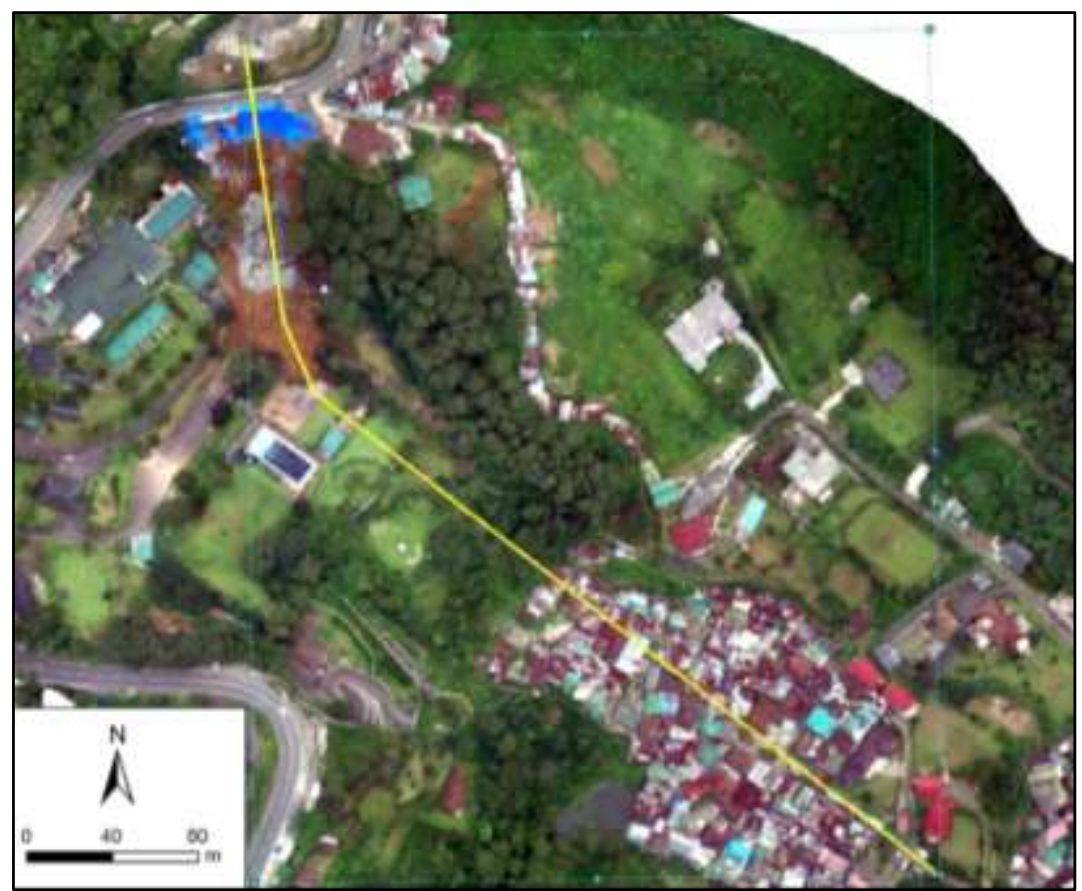

Gambar 3 Peta kawasan longsor hasil pemetaan dari drone, dan garis penampang melintang profil topografi sampai dengan permukiman yang berada di bawahnya (Sumber: Hasil analisis)

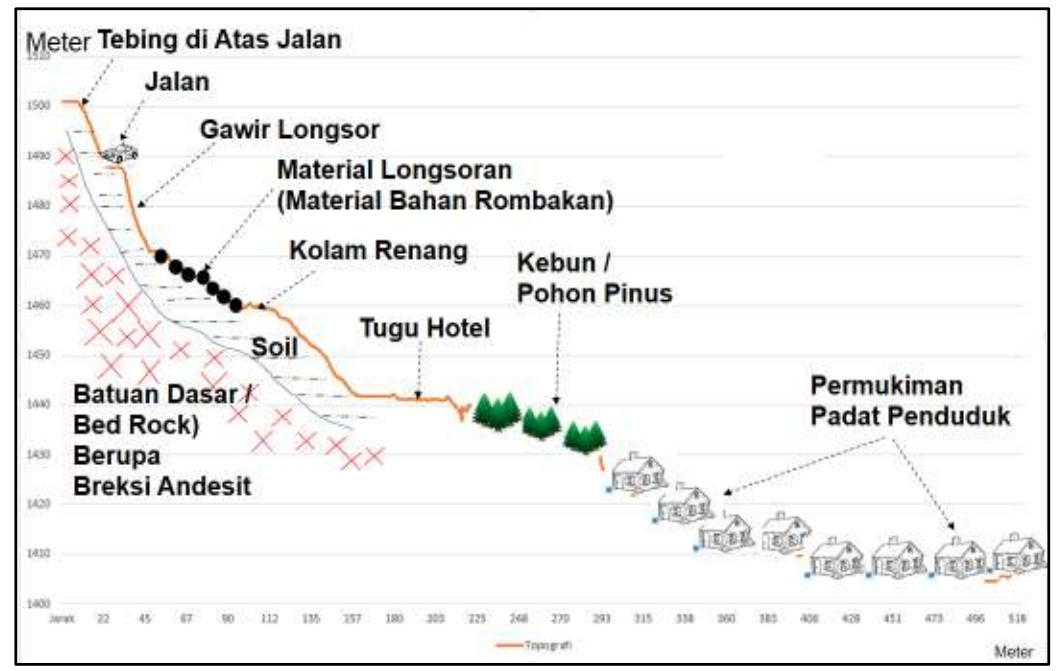

Gambar 4 Skematik profil topografi pada garis penampang melintang sampai dengan permukiman yang berada di bawahnya (Sumber: Hasil analisis).

\section{Faktor-Faktor Pendukung Terhadap Kejadian Tanah Longsor}

\section{Kondisi Geologi}

Berdasarkan peta geologi yang dikeluarkan oleh Badan Geologi, daerah Puncak Pass terbentuk oleh Breksi dan Lava Gunung Kencana dan Gunung Limo (Qvk) yang berumur Kuarter, terdiri dari: bongkahan andesit dan breksi andesit dengan banyak sekali fenokris piroksen dan lava basal (Effendi et al., 1998). Hasil survei lapangan didapatkan adanya breksi dengan fragmen berupa batuan beku andesit, dengan tingkat pelapukan sangat tinggi. Menurut informasi dari pengelola Puncak Pass Resort, pondasi bangunan yang dibangun sampai kedalaman 12 meter dan belum sampai pada batuan dasar, yang artinya kedalaman soil lebih dari 12 meter. Retakan-retakan tanah/batuan terjadi di sekitar lokasi longsor, baik sebelum maupun setelah 
kejadian bencana. Retakan tersebut menjadi salah satu media air permukaan untuk lebih cepat masuk ke dalam tanah/batuan.

Topografi

Lokasi longsor di Puncak Pass berada 1.490 meter di atas permukaan air laut (dpl). Secara umum kondisi morfologi di daerah bencana merupakan perbukitan dengan kemiringan tingkat lereng curam sampai sangat curam. Lereng tanah longsor setelah kejadian mempunyai dengan kemiringan $80^{\circ}-90^{\circ}$, sementara pada lereng bagian bawah kemiringan berkisar antara $20^{\circ}-30^{\circ}$. Tinggi longsoran di sekitar mahkota kurang lebih 25 meter.

Hasil analisis profil kelerengan tebing serta penampang melintang pada lokasi longsor, menunjukkan bahwa klasifikasi prosentase kelerengan di sekitar daerah longsor sebagian besar mempunyai kelerengan lebih besar 30\% (Gambar 6). Daerah sekitar Puncak Pass merupakan puncak dari jalan raya Bogor-Cianjur yang merupakan perbukitan, sehingga dominasi kelerengan di atas 30\% paling besar (Naryanto et al., 2018).

Daerah lokasi longsor dan permukiman penduduk yang berada di bawahnya masih berada dalam sebuah sistem Sub-DAS yang relatif tidak terlalu besar (Gambar 7). Menurut Zuma et al. (2017), Daerah Aliran Sungai merupakan suatu daerah yang dibatasi oleh topografi secara alami dimana air hujan yang jatuh di atasnya akan mengalir keluar melalui suatu outlet yang sama. Daerah tangkapan air pada sistem Sub-DAS di lokasi longsor tersebut relatif tidak terlalu luas. Sementara sebagian daerah permukiman berada di bawah sistem Sub-DAS tersebut. Berdasarkan data ini permukiman tersebut dapat dikategorikan dalam bahaya sedang sampai dengan tinggi (Naryanto et al., 2018).

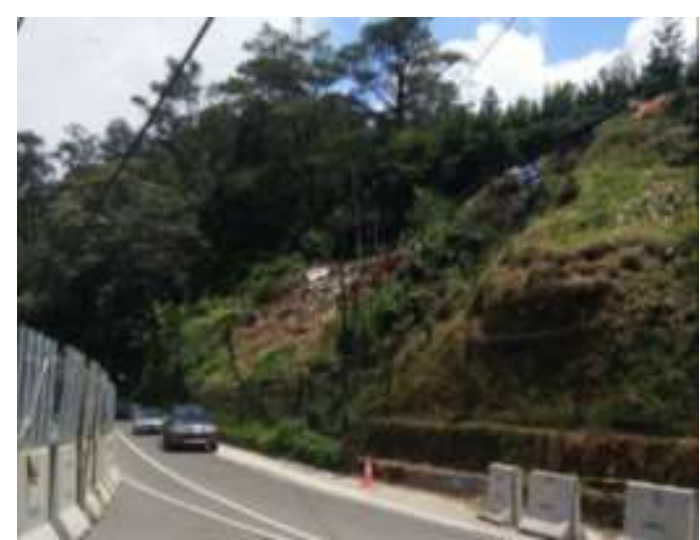

Gambar 5 Kondisi morfologi dan kelerengan pada sekitar kawasan longsor.

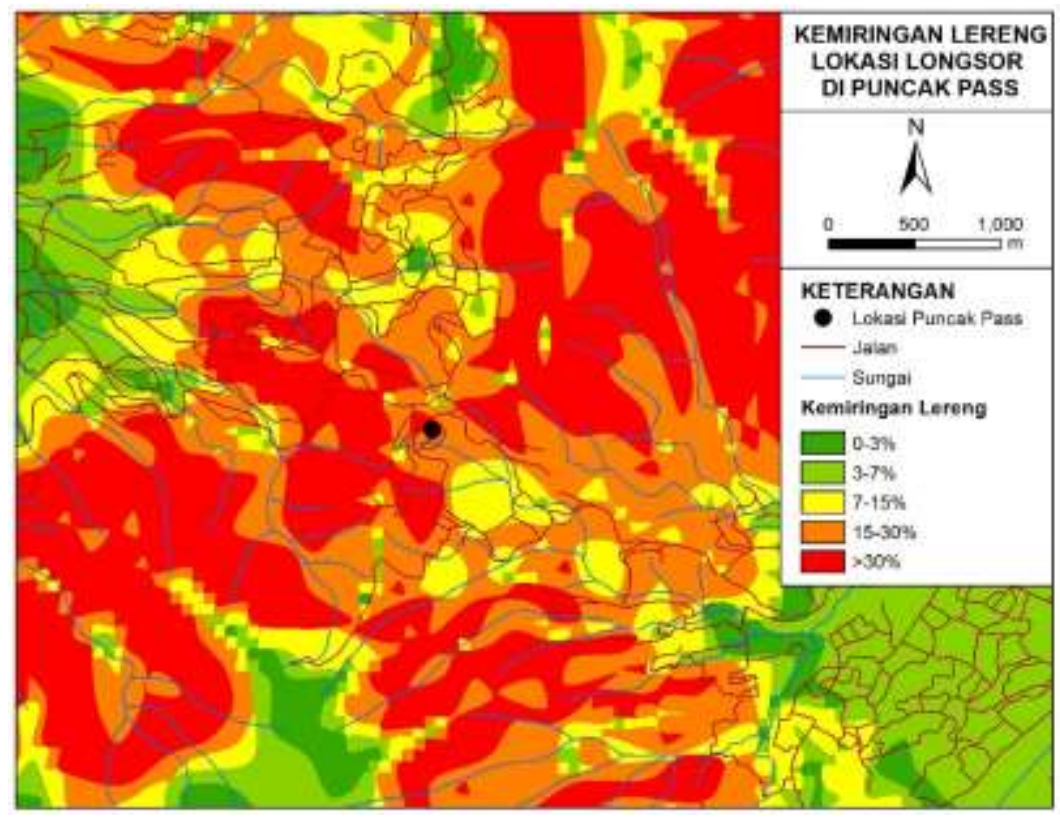

Gambar 6 Prosentase kelerengan pada daerah sekitar longsor (Sumber: Hasil analisis). 


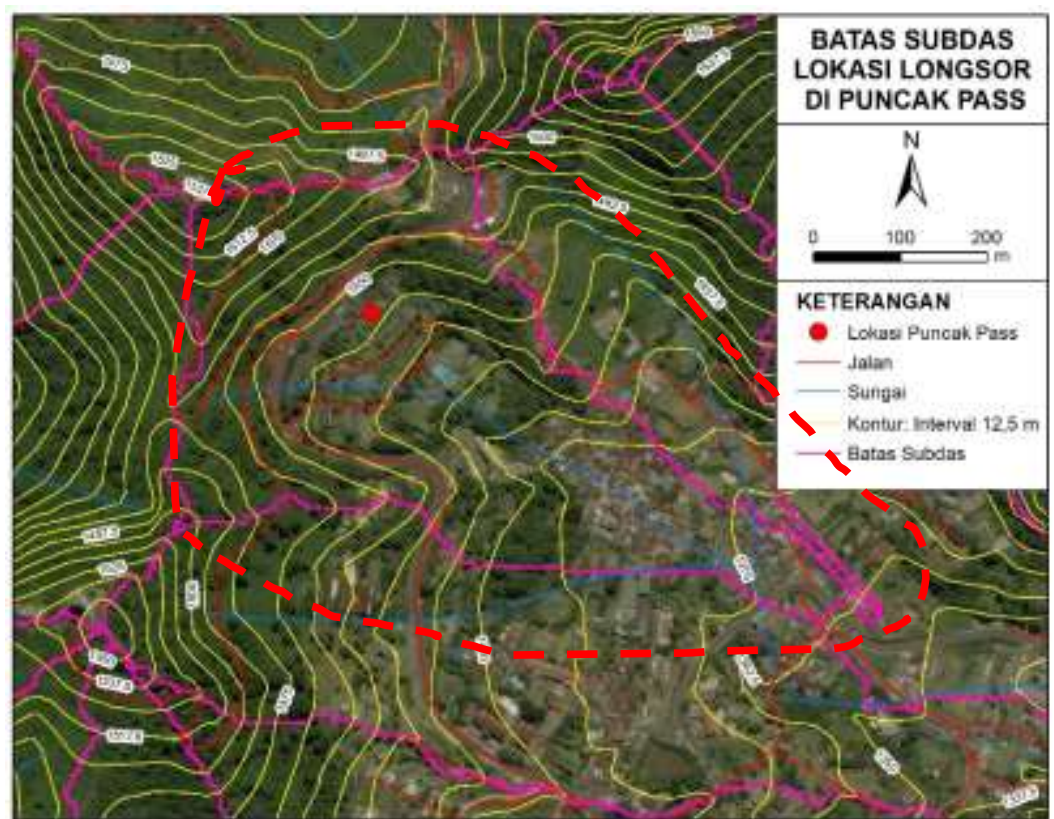

Gambar 7 Sistem sub DAS pada daerah longsor (Sumber: Hasil analisis).

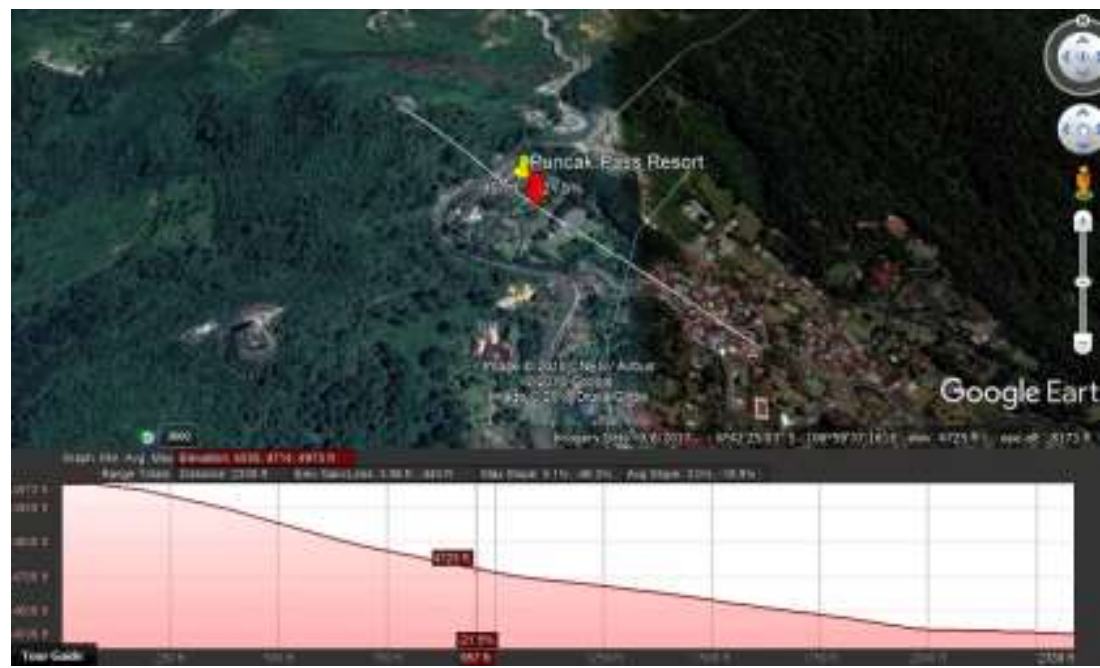

Gambar 8 Penampang melintang (cross section) topografi Puncak Pass sebelum longsor (Sumber: Hasil analisis menggunakan peta Google Earth).

\section{Tataguna Lahan}

Secara umum tataguna lahan yang berada pada sekitar lokasi longsor berupa tanaman perkebunan, hutan, tanaman lahan kering, tanaman ladang dan permukiman. Tataguna lahan pada daerah longsor didominasi oleh hutan pinus. Terlihat pada gambar foto udara pada saat sebelum longsor, bahwa seluruh daerah longsor adalah bagian dari hutan pinus yang didelineasi warna hijau dengan luas sebesar 2.14 hektar, setelah longsor luas hutan pinus berkurang menjadi 1.6 hektar (Gambar 9). 

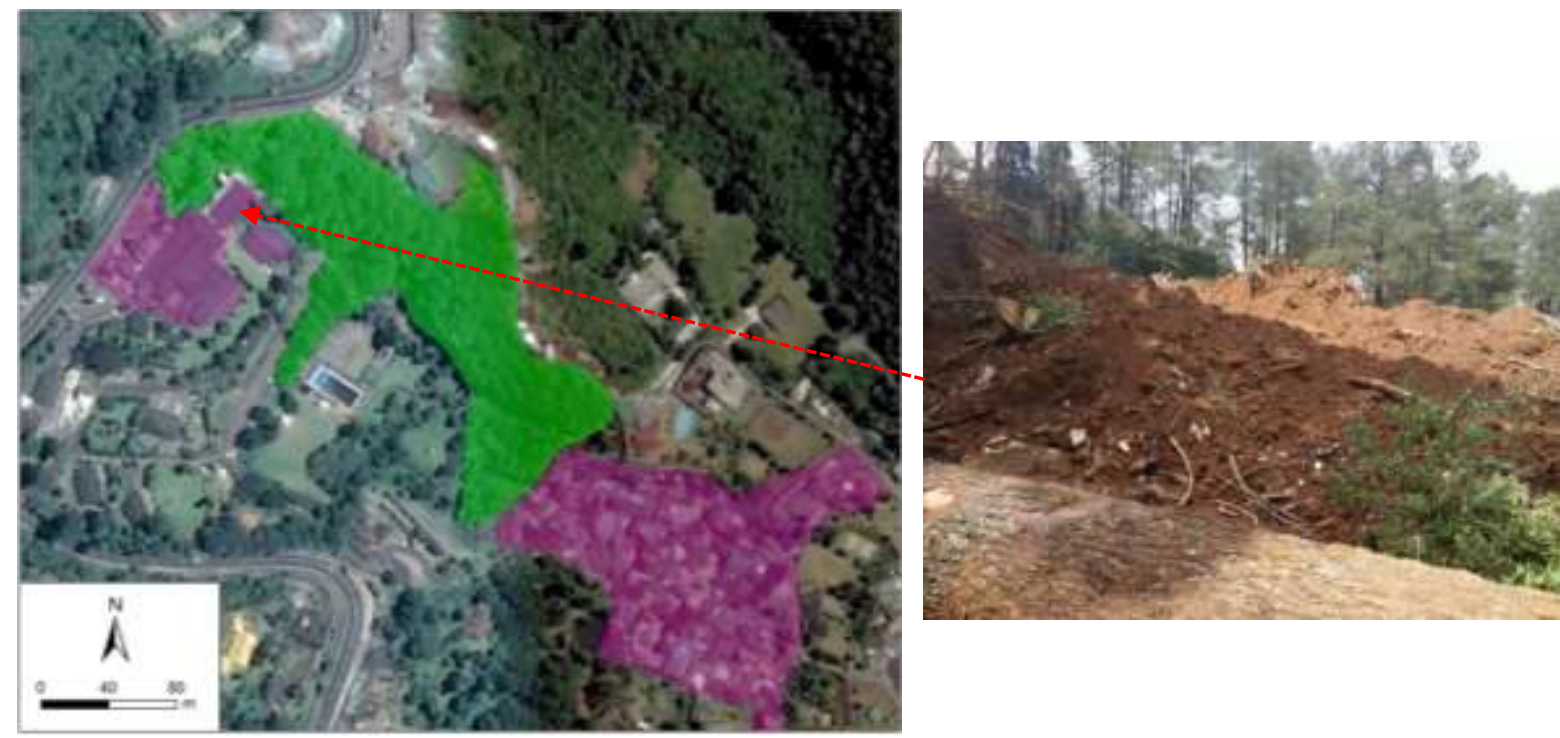

Gambar 9 Tataguna lahan yang didominasi oleh hutan pinus di lokasi sekitar longsor sebelum bencana terjadi (Sumber: Hasil analisis dari peta Google Earth dan lapangan).

\section{Curah Hujan}

Data curah hujan diatas didapat dari web http://dataonline.bmkg.go.id. Data tersebut berasal dari pengukuran di Stasiun Meteorologi Citeko yang memang berada di daerah Puncak. Dari grafik tersebut diatas terlihat bahwa tidak terjadi hujan deras pada tanggal 28 Maret 2018. Hujan cukup deras terjadi pada tanggal 21 sd 23 Maret 2018 lalu terjadi lagi pada tanggal 25 dan 26 Maret 2018.

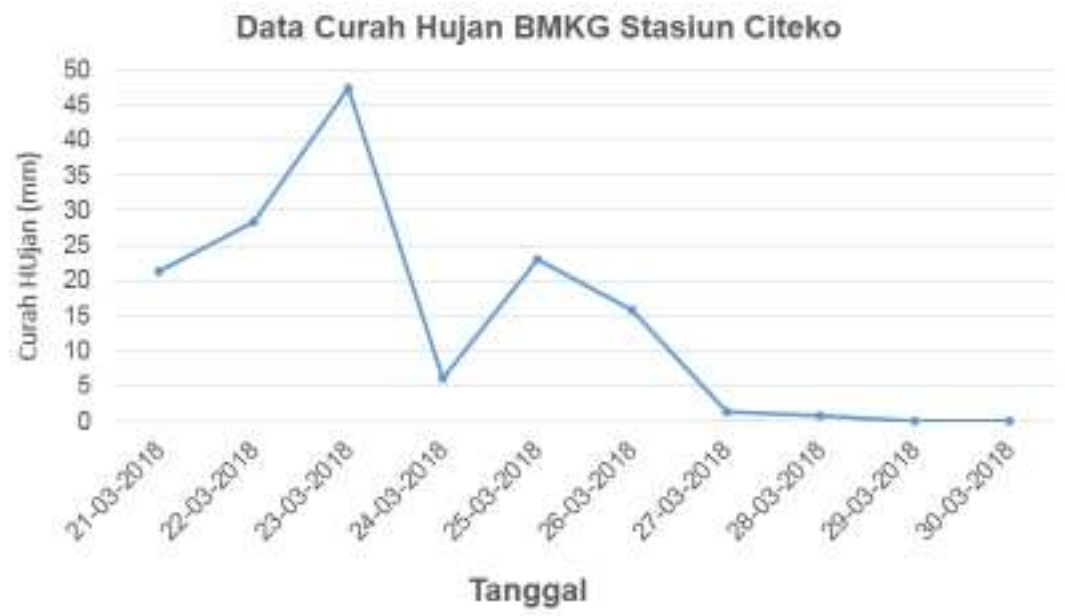

Gambar 10 Data curah hujan dari pengukuran di Stasiun Meteorologi Citeko (Puncak) dari tanggal 21 Sampai 30 Maret 2018 (Sumber: http://dataonline.bmkg.go.id).

\section{Keairan dan Drainase}

Secara umum drainase kondisinya kurang tertata dengan baik. Daerah di atas lokasi longsor berupa jalan, air permukaan yang jatuh langsung mengalir ke lokasi yang lebih rendah termasuk ke lokasi longsor. Banyaknya air permukaan yang masuk ke daerah longsor yang sebelum kejadian banyak dijumpai rekahanrekahan tanah, hal ini akan mempercepat terjadinya kejenuhan tanah untuk menjadi longsor.

Di dalam lingkungan Hotel Puncak Pass dijumpai beberapa mata air, termasuk pada bagian kaki lereng yang mengalir ke arah permukiman padat penduduk yang berada di bawahnya. Pada saat hujan deras debit mata air meningkat, dan ini yang perlu diwaspadai karena menyebabkan kejenuhan tanah menjadi meningkat dan ketidakstabilannya juga meningkat untuk menjadi tanah longsor. 


\section{Pengaruh Aktivitas Manusia}

Daerah bagian atas lokasi longsor berupa jalan yang sangat padat lalu-lintasnya, sehingga beban dan getaran dari transportasi tersebut sangat mengganggu terhadap kestabilan tanah dan lereng di bagian bawahnya. Lereng terjal di bawah dan di atas jalan juga sangat mempengaruhi terjadinya ketidakstabilan lereng, akibat beban dan getaran transportasi sehingga mudah runtuh.

\section{Faktor Penyebab Utama dan Mekanisme Longsor}

\section{Faktor Penyebab Terjadinya Tanah Longsor}

Secara umum faktor penyebab terjadinya tanah longsor di daerah penelitian antara lain adalah:

- Kemiringan lereng yang terjal $\left(>60^{\circ}\right)$

- Tanah pelapukan yang tebal menumpang di atas batuan breksi andesit

- Curah hujan dengan intensitas cukup tinggi pada hari-hari sebelumnya memicu terjadinya longsor.

- Beban transportasi jalan yang berada di atas lokasi longsor

- Terbentuknya mata air di sekitar longsor

\section{Mekanisme Terjadinya Tanah Longsor}

Curah hujan yang cukup tinggi pada hari-hari sebelum terjadi longsor, saluran drainase yang kurang baik dan kelerengan terjal menyebabkan air hujan masuk ke dalam tanah melalui daerah tangkapan air (recharge area) serta retakan-retakan di sekitar longsor sehingga jenuh air. Permasalahan longsor ditambah dengan beban dan getaran transportasi jalan yang sangat padat, munculnya mata air pada sekitar longsor serta lemahnya lokasi longsor akibat kejadian longsor sebelumnya. Akibatnya bobot masanya tanah bertambah menyebabkan kekuatan gesernya menurun, sehingga tanah tidak stabil (mudah bergerak). Tanah pelapukan dan yang menumpang pada batuan breksi andesit dengan kemiringan terjal tersebut menyebabkan terjadinya gerakan tanah tipe longsoran bahan rombakan (debris slide).

\section{Penataan Kawasan Sekitar Lokasi Longsor}

\section{Penanganan Tanah Longsor Saat ini}

Menurut informasi dari Kemen PUPR, untuk penanganan sementara akan kembali memasang bronjong yang sebelumnya juga sempat runtuh karena longsor di lokasi yang sama. Hal ini dilakukan agar jalan bisa segera dilalui roda empat dari kedua arah. Perbaikan dilakukan secara permanen dengan menggunakan konstruksi bore pile atau sejenis paku bumi. Pemasangan paku bumi dilakukan mengingat di bawah tanah lokasi longsor terdapat aliran air. Hal itulah yang diduga menjadi penyebab longsor (Tempo.co, 2018).

\section{Penentuan Lokasi Jalan Baru}

Perbaikan jalan yang rusak akibat longsor paling tepat adalah dengan cara pelebaran jalan lama yang memotong lereng bukit yang ada di atasnya. Pemotongan bukit di bagian atasnya terlebih dulu harus mengosongkan warung-warung yang berada di atasnya. Pemotongan jalan harus memperhatikan faktor kestabilan lereng, tidak terlalu curam dan mengingat beda ketinggian jalan dan bukit di atasnya cukup besar sehingga pembangunan lereng perlu dilakukan konstruksi beton yang kuat atau pembuatan shotcrete (beton tembak).

\section{Tata Air dan Drainase}

Kondisi tata air dan drainase saat ini kurang tertata rapi, sehingga perlu direncanakan ke depan pembuatan drainase di bawah tebing hasil pelebaran jalan baru, gorong-gorong pembuangan dari saluran drainase yang memotong jalan untuk disalurkan ke tempat yang lebih rendah, drainase pada bukit di atas jalan, permukiman 
serta di sekitar hotel. Mata air muncul di taman hotel bagian belakang. Saluran drainase yang baik sangat diharapkan untuk secepatnya membuang air tersebut ke arah permukiman di bawahnya, supaya tidak menggenang dan menjenuhi tanah yang meningkatkan potensi terhadap longsor.

\section{Penguatan Tebing}

Penguatan tebing diperlukan pada pelebaran jalan yang memotong tebing di atasnya dengan konstruksi struktur beton yang kuat serta pada tebing bekas terjadinya longsor. Penguatan tebing yang kuat juga diperlukan pada belokan jalan tajam timur lokasi longsor, belokan jalan timur lokasi longsor serta tebing bagian utara resort, serta tebing di bawah jalan yang merupakan terusan tebing yang telah terjadi longsor.

\section{Penataan Lahan}

Perubahan penggunaan lahan merupakan faktor pemicu penting terjadinya bencana longsor. Penggunaan lahan dengan vegetasi berperakaran dangkal berkontribusi terhadap ketidakstabilitas lereng. Interaksi hutan dengan kejadian longsor merupakan fenomena yang kompleks. Semakin rapat proporsi tutupan hutan, maka semakin rendah jumlah lereng/tanah yang tererosi oleh hujan (Glade, 2003; Ramadhan et al., 2016).

Daerah penelitian merupakan bagian dari puncak jalan suatu topografi tinggi yang berada di kawasan Puncak. Karena merupakan kawasan resapan dan bertopografi terjal, sebaiknya penghijauan dengan tanaman besar dan berakar kuat lebih diprioritaskan. Pada bagian atas lokasi longsor yang sebagian diratakan untuk pelebaran jalan, sebelumnya merupakan warung-warung dan tempat parkir pengunjung. Dengan pengosongan kawasan tersebut akibat pelebaran jalan, maka penghijauan kembali kawasan tersebut akan bisa menambah daerah resapan yang bisa menahan air untuk disimpan ke dalam tanah. Penghijauan juga segera dilakukan pada kawasan yang terkena dampak longsor di sekitar resort dengan pohon pinus yang sudah banyak tumbuh di sekitarnya untuk menahan tanah dan meresapkan air permukaan dalam rangka mengurangi bahaya longsor. Salah satu hal yang sangat penting adalah penghijauan di atas permukiman yang merupakan lahan milik resort. Potensi longsor tipe rayapan terjadi pada kawasan tersebut, sehingga untuk menghindari longsoran lebih besar lagi maka penghijauan atau juga pembuatan beton atau bronjong sangat dibutuhkan.

\section{Permukiman Potensi Terdampak}

Terdapat kurang lebih 100 rumah yang kemungkinan akan terdampak longsor pada daerah ini. Perhitungan lebih detil diperlukan untuk kalkulasi jumlah kerugian yang mungkin terjadi apabila longsor menyebar dan berlanjut sampai ke arah permukiman. Jarak dari ujung longsor dari perumahan terdekat adalah 140 meter (Gambar 12). Oleh karena itu perlu dilakukan langkah langkah preventif untuk meminimalisir risiko longsor. Perhitungan permukiman bisa terkena bencana longsor, apabila longsor tipe longsoran bahan rombakan (debris slide) yang pernah terjadi bercampur dengan air akibat hujan tinggi sehingga berkembang menjadi aliran bahan rombakan (debris flow), atau bahaya longsor tipe rayapan mengandung air dengan jumlah sangat besar sehingga bisa berkembang menjadi aliran bahan rombakan. 


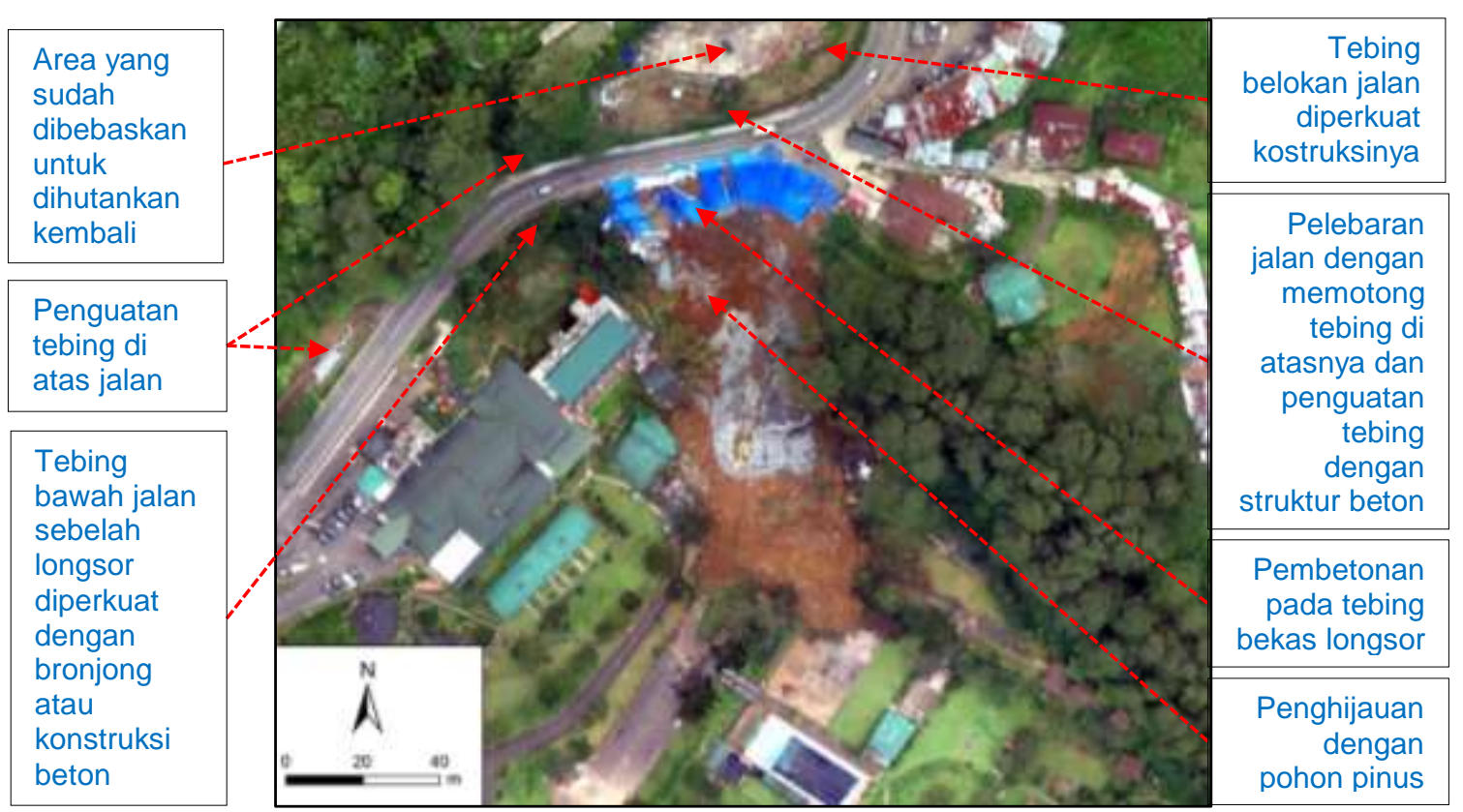

Gambar 11 Penataan kawasan sekitar longsor Puncak Pass (Sumber: Hasil analisis).
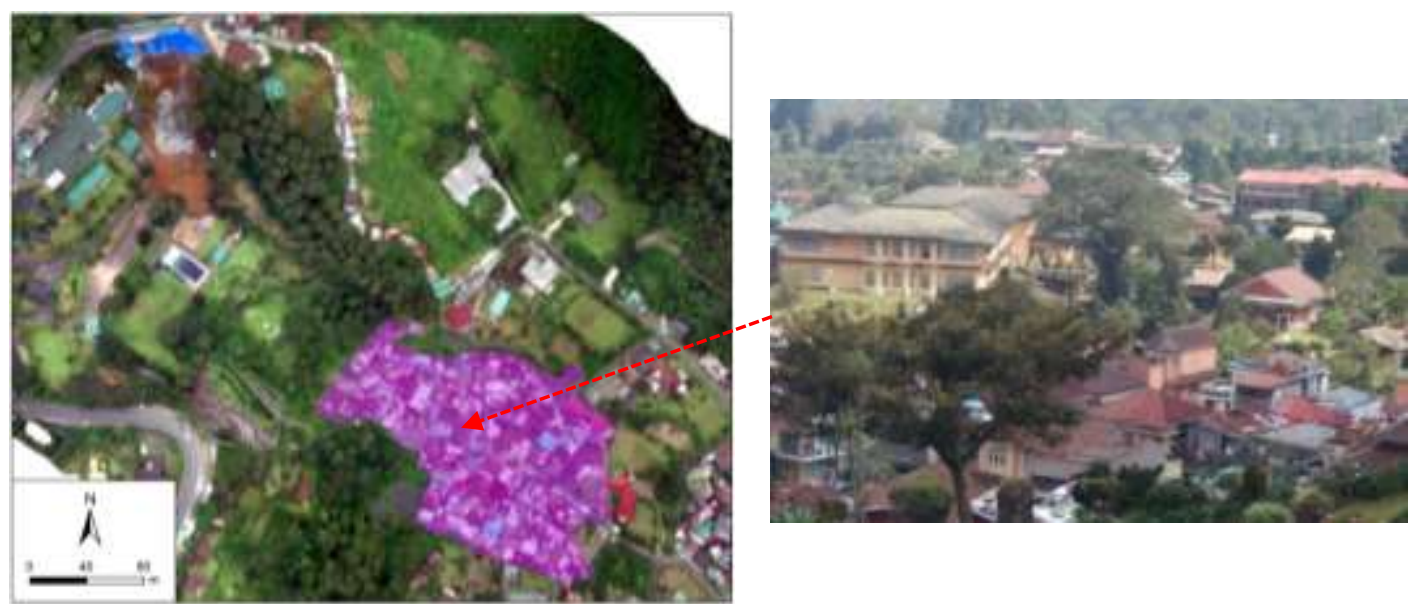

Gambar 12 Foto udara pemukiman padat penduduk yang berada di bawah lokasi longsor yang berpotensi terkena dampak longsor (Sumber: Hasil analisis).

\section{Mitigasi Bencana Tanah Longsor}

Beberapa kegiatan pengurangan risiko bencana tanah longsor di kawasan Puncak Pass, antara lain adalah:

- Pembentukan atau pematangan kesiapsiagaan masyarakat serta aparat serta rencana kontigensi terhadap kegiatan di sekitar longsor terutama saat dan setelah terjadi hujan yang tinggi atau berlangsung lama.

- Pembangunan sistem peringatan dini bahaya tanah longsor baik yang berbasis masyarakat maupun instrumen khususnya berbasis curah hujan atau Automatic Weather Station (AWS).

- Tidak beraktivitas di sekitar lokasi tanah longsor di lembah yang berpotensi menjadi jalan pergerakan material longsoran serta pada tebing curam pada saat atau setelah hujan dengan intensitas tinggi.

- Pemasangan rambu-rambu peringatan rawan longsor pada jalur jalan dan pada tempat-tempat yang rawan longsor.

- Penguatan organisasi, sosialisasi, pendidikan dan latihan bencana tanah longsor kepada masyarakat dan aparat.

- Pemetaan detail di sekitar lokasi longsor yang berpotensi dan berisiko bencana tanah longsor, untuk dasar dalam pengurangan risiko bencana tanah longsor. 


\section{SIMPULAN}

Bencana tanah longsor telah terjadi di Puncak Pass, Kecamatan Cipanas, Kabupaten Cianjur, Jawa Barat pada hari Rabu 28 Maret 2018 dengan persebaran material longsor sampai sejauh 125 meter. Tipologi tanah longsor yang terjadi adalah longsoran bahan rombakan jenis rotasi yang berbentuk cekungan seperti tapal kuda. Banyak faktor-faktor yang mempengaruhi terjadinya tanah longsor di di Puncak Pass, adalah: kondisi geologi, topografi, tataguna lahan, curah hujan, keairan dan drainase serta pengaruh aktivitas manusia. Hasil analisis ada tiga faktor utama penyebab terjadinya tanah longsor tersebut yaitu: topografi pembentuk tanah longsor sangat terjal, terjadinya hujan lebat selama beberapa hari berturut-turut sebelum terjadi longsor, serta lereng yang selalu terganggu beban transportasi kendaraan di atasnya.

Penataan kawasan longsor sangat penting untuk menata kembali kondisi kawasan tersebut yang aman berkelanjutan terhadap bencana tanah longsor serupa di masa yang akan datang. Penataan tersebut adalah: penanganan tanah longsor saat tanggap darurat, penentuan lokasi pengembangan jalan baru, pengelolaan tata air dan drainase, penguatan tebing, penataan lahan, permukiman potensi terdampak, serta pengurangan risiko bencana tanah longsor. Diperlukan pembangunan sistem peringatan dini bahaya tanah longsor baik yang berbasis masyarakat maupun instrumen khususnya berbasis curah hujan. Tidak beraktivitas di sekitar lokasi tanah longsor di lembah yang berpotensi menjadi jalan pergerakan material longsoran serta pada tebing curam pada saat atau setelah hujan dengan intensitas tinggi. Pembentukan atau pematangan kesiapsiagaan masyarakat serta aparat, penguatan organisasi, rencana kontigensi, sosialisasi, pendidikan dan latihan terkait kegiatan pengurangan risiko bencana tanah longsor pada kawasan rawan longsor. Selain itu diperlukan pemetaan detail di sekitar lokasi longsor yang berpotensi dan berisiko bencana tanah longsor.

\section{DAFTAR PUSTAKA}

BMKG. 2018. Data curah hujan dari pengukuran di Stasiun Meteorologi Citeko (Puncak) dari tanggal 21 Sampai 30 Maret 2018; [diunduh 2018 April 7]. Tersedia pada: http://dataonline.bmkg.go.id.

Effendi AC, Kusuma, Hermanto B. 1998. Peta Geologi Lembar Bogor, Jawa. Bandung: Pusat Penelitian dan Pengembangan Geologi.

Effendi, Danil A. 2008. Identifikasi Kejadian Longsor dan Penentuan Faktor-Faktor Utama Penyebabnya di Kecamatan Babakan Madang Kabupaten Bogor. Bogor: Departemen Manajemen Hutan Fakultas Kehutanan Institut Pertanian Bogor.

Glade T. 2003. Landslides occurence as aresponse to land use change: A review of evidence from New Zealand. Catena. (51): 297-314.

Naryanto HS, Prawiradisastra F, Kristijono A. 2018. Laporan kajian singkat bencana tanah longsor di Puncak Pass, Kecamatan Cipanas, Kabupaten Cianjur, Jawa Barat tanggal 28 Maret 2018. Laporan internal. Jakarta: PTRRB-BPPT.

Naryanto HS. 2011. Analisis risiko bencana tanah longsor di Kabupaten Karanganyar, Provinsi Jawa Tengah. Jurnal Penanggulangan Bencana. 2(1): 21-32.

Naryanto HS. 2013. Analisis dan evaluasi kejadian bencana tanah longsor di Cililin, Kabupaten Bandung Barat, Provinsi Jawa Barat Tanggal 25 Maret 2013. Jurnal Sains dan Teknologi Mitigasi Bencana. 8(1): $39-49$.

Naryanto HS. 2016. Penerapan Ilmu Pengetahuan dan Teknologi dalam Pengurangan Risiko Bencana Tanah Longsor (Gerakan Tanah) di Indonesia. Jakarta: BPPT Press.

Naryanto HS. 2017. Analisis kejadian bencana tanah longsor di Dusun Jemblung, Desa Sampang, Kecamatan Karangkobar, Kabupaten Banjarnegara, Provinsi Jawa Tengah Tanggal 12 Desember 2014. Jurnal Alami. 1(1): 1-9.

Paimin, Sukresno, Pramono IB. 2009. Teknik Mitigasi Banjir dan Tanah Longsor. Balikpapan: Tropenbos International Indonesia Programme. 
PVMBG, 2016. Gerakan tanah, buklet gerakan tanah; [diunduh 2018 Mei 18]. Tersedia pada: http://pvmbg.geologi.esdm.go.id/index.php/kegiatan-pvmbg/download-center/cat_view/88publikasi/114-leafletbooklet.

PVMBG, 2018. Laporan singkat pemeriksaan gerakan tanah di Kp. Puncak, Desa Ciloto, Kecamatan Cipanas, Kabupaten Bogor, Provinsi Jawa Barat; [diunduh 2018 April 6]. Tersedia pada: http://www.vsi.esdm.go.id/index.php/gerakan-tanah/kejadian-gerakan-tanah/2122-laporan-singkatpemeriksaan-gerakan-tanah-di-kp-puncak-desa-ciloto-kecamatan-cipanas-kabupaten-bogor-provinsijawa-barat.

Rahman AZ. 2017. Kapasitas daerah Banjarnegara dalam penanggulangan bencana alam, tanah longsor. Jurnal Ilmu Sosial. 16(1): 1-8.

Ramadhan R, Widiatmaka, Sudadi U. 2016. Perubahan penggunaan lahan dan pemanfaatan ruang pada wilayah rawan longsor di Kabupaten Banjarnegara, Jawa Tengah. Jurnal Pengelolaan Sumberdaya Alam dan Lingkungan. 6(2): 159-167.

Sartohadi J. 2008. The landslide distribution in Loano Sub-District, Purworejo District, Central Java Province, Indonesia. Forum Geografi. 22(2): 129-144.

Tempo.co. 2018. Perbaikan longsor, tebing di Puncak dikupas 2 meter; [diunduh 2018 April 8]. Tersedia pada: https://metro.tempo.co/read/1074878/perbaikan-longsor-tebing-di-puncak-dikupas-2-meter.

Varnes DJ. 1978. Slope movement: types and processes. In: Schuster, R.L. and Krizek, R.J., Eds., Landslides, analysis and control. Transportation Research Board, Special Report No. 176, National Academy of Sciences: $11-33$.

Wang F, Xu P, Wang C, Wang N, Jiang, N. 2017. Application of a GIS-based slope unit method for landslide susceptibility mapping along the Longzi River, Southeastern Tibetan Plateau, China. ISPRS International Journal of Geo-Information. 6(6): 172.

Zuma DS, Murtilaksono K, Suharnoto Y. 2017. Analisis curah hujan dan debit model SWAT dengan metode moving average di DAS Ciliwung hulu. Jurnal Pengelolaan Sumberdaya Alam dan Lingkungan. 7(2): 98-106. 